\title{
Other longitude: intriguing results
}

\author{
Stefanos Demertzis, MD
}

\footnotetext{
From the Department of Cardiac Surgery, Cardiocentro Ticino, Lugano, Ticino, Switzerland; Faculty of Medicine, University of Bern, Bern, Switzerland; and Faculty of Biomedical Sciences, University of Italian Switzerland, Lugano, Ticino, Switzerland.

Disclosures: Author has nothing to disclose with regard to commercial support.

Received for publication June 25, 2018; revisions received June 25, 2018; accepted for publication June 27, 2018; available ahead of print Aug 21, 2018

Address for reprints: Stefanos Demertzis, MD, Department of Cardiac Surgery, Cardiocentro Ticino, Via Tesserete 48 CH-6900, Lugano, Switzerland (E-mail: demertzis@ cardiocentro.org).

J Thorac Cardiovasc Surg 2019;157:149-50

$0022-5223 / \$ 36.00$

Copyright (C) 2018 by The American Association for Thoracic Surgery

https://doi.org/10.1016/j.jtcvs.2018.06.068
}

\section{Variety is the very spice of life.} -William Cowper, "The Task," 1785

Use of as many arterial grafts as possible is accepted as an effective way to achieve long-lasting results after surgical coronary revascularization $(\mathrm{CABG})$ and to counteract the sequelae of venous graft disease. In a famous retrospective observational study, ${ }^{1}$ the use of both internal thoracic arteries (ITAs) was associated with better long-term outcome and survival. Since then, times and patient selection for CABG has changed significantly. The use of bilateral in situ ITA remained, however, a continuous matter of debate, perhaps also due to the lack of a prospective randomized trial as a solid scientific basis. To the continuous debate contributed also the association of bilateral ITA use with a higher incidence of deep sternal wound infections (DSWIs), especially in patients with diabetes. ${ }^{2,3}$ An interim analysis at 5 years' follow-up of the first, specifically designed prospective randomized trial added uncertainty and challenged the influence of the use of bilateral ITA on outcomes, ${ }^{4}$ although the final analysis needs to be awaited before jumping to conclusions. This interim analysis, however, confirmed a significantly higher incidence of DSWI in the bilateral ITA versus the single ITA group $(3.5 \%$ vs $1.9 \%)$.

There are significant differences between geographic regions of the Western world regarding the frequency of bilateral ITA use: In the United States it is only around $4 \%$ and in Europe around $12 \%$. $^{5}$

With all this mind, Ohira and colleagues ${ }^{6}$ offer an important contribution to our knowledge for several reasons: their research is based on a validated, prospective national database in Japan and it includes data of 560 hospitals corresponding to roughly 14,000 patients. The degree of bilateral ITA use was variable; the average, however, was an impressive 33\% (more than 8-fold the US average and more than double the European average) of all CABGs, most of them $(>70 \%)$ are performed off-pump. Already with these basic data, it is undeniable that the article describes a different patient and surgery landscape than that found in the United States and Europe. The article focuses

\section{References} 163-70.

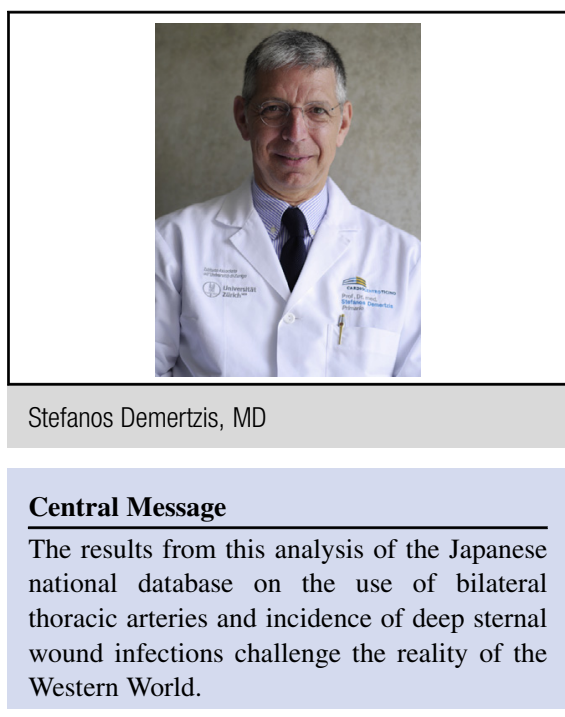

See Article page 166.

on the analysis of DSWI after bilateral ITA use (beware of some slight nonsignificant differences in the definition of DSWI between the Japanese database and the Society of Thoracic Surgeons database). The reported incidence was low $(1.6 \%)$ despite more than $50 \%$ of patients receiving bilateral ITA also having diabetes. Female sex, diabetes mellitus, chronic lung disease, renal failure, liver dysfunction, ejection fraction $\leq 60 \%$, shock status, reoperation, preoperative intra-aortic balloon pump use, and an increased operative time were independent risk factors for DSWI after bilateral ITA grafting. Some interesting questions remain unanswered. To name a few: How important is the degree of blood glucose control pre- and postoperatively? and, What was the technique of ITA takedown? This scientifically valid article and the presented results should motivate us to try to understand why differences to our reality occur. More detailed and specific studies and analyses could contribute to a better evidence-based match of patient and graft selection and help us to further optimize (perhaps even personalize) surgical coronary revascularization and its influence on the lives of our patients.

1. Lytle BW, Blackstone EH, Sabik JF, Houghtaling P, Loop FD, Cosgrove DM The effect of bilateral internal thoracic artery grafting on survival during 20 postoperative years. Ann Thorac Surg. 2004;78:2005-12.

2. Deo SV, Altarabsheh SE, Shah IK, Cho YH, McGraw M, Sarayyepoglu B, et al Are two really always better than one? Results, concerns and controversies in the use of bilateral internal thoracic arteries for coronary artery bypass grafting in the elderly: a systematic review and meta-analysis. Int J Surg. 2015;16(Pt B): 
3. Savage EB, Grab JD, O'Brien SM, Ali A, Okum EJ, Perez-Tamayo RA, et al. Use of both internal thoracic arteries in diabetic patients increases deep sternal wound infection. Ann Thorac Surg. 2007;83:1002-6.

4. Taggart DP, Altman DG, Gray AM, Lees B, Gerry S, Benedetto U, et al Randomized trial of bilateral versus single internal-thoracic-artery grafts. N Engl J Med. 2016;375:2540-9.
5. Kappetein AP. Bilateral mammary artery vs. single mammary artery grafting: promising early results: but will the match finish with enough players? Eur Heart J. 2010;31:2444-6.

6. Ohira S, Miyata H, Yamazaki S, Numata S, Motomura N, Takamoto S, et al. Deep sternal wound infection after bilateral internal thoracic artery grafting: insights from a Japanese national database. J Thorac Cardiovasc Surg. 2019;157:166-73.e1. 